\title{
Frequency of antibodies and risk factors associated with Toxoplasma gondii infection in backyard pig production in the city of Mossoró, state of Rio Grande do Norte, Brazil
}

Frequência de anticorpos e fatores de risco associados à infecção por Toxoplasma gondii em criaçóes de suínos em Mossoró, Rio Grande do Norte

Isabela Maria Campanelli dos Santos ${ }^{1}$; Alexandro Iris Leite ${ }^{2}$; Maria Eduarda Chiaradia Furquim ${ }^{1}$;

Diego Carlos de Souza Zanatto ${ }^{1}$; Simone de Jesus Fernandes ${ }^{1}$; Glaucenyra Cecília Pinheiro da Silva ${ }^{3}$;

Paulo Henrique Sampaio ${ }^{1}$; Rosangela Zacarias Machado ${ }^{1}$; Marcos Rogério André ${ }^{*}$ (i)

\author{
${ }^{1}$ Departamento de Patologia Animal, Universidade Estadual Júlio de Mesquita Filho - UNESP, Jaboticabal, SP, Brasil \\ ${ }^{2}$ Departamento de Ciência Animal, Universidade Federal Rural do Semi-Árido - UFERSA, Mossoró, RN, Brasil \\ ${ }^{3}$ Departamento de Medicina Veterinária Preventiva e Reprodução Animal, Universidade Estadual Júlio de Mesquita Filho - UNESP, \\ Jaboticabal, SP, Brasil
}

Received November 29, 2018

Accepted April 29, 2019

\begin{abstract}
Toxoplasmosis is an important zoonosis for pregnant women and immunosuppressed people. The pig population also becomes infected by this pathogen, and undercooked or raw meat is an important source of infection for humans. The aims of the present study were to evaluate the rate of exposure of pigs to T. gondii in the municipality of Mossoró, Rio Grande do Norte and seek to identify associations with possible risk factors. Blood samples were collected from 412 pigs and were analyzed using the immunofluorescence assay. Among these 412 serum samples, $40.7 \%$ were seropositive for T. gondii. The IgG antibody titers were 64 (56 specimens), 128 (32), 256 (37), 512 (23), 1024 (14), 2048 (5) and 4046 (1). Seropositivity for T. gondii was found to be related ( $p$-value $<0.05$ ) to the following factors: female gender, semi-confined rearing system, use of well water, dewormed animals, presence of cats, goats, sheep, mice and vultures on the farm and carcasses left on the ground. In contrast, seropositivity was not related $(p$-value $<0.05)$ to the age of the pigs, type of facility or feeding with human food remains. Preventive measures need to be adopted on the farms studied here, with the aim of decreasing the animals' intake of sporulated oocysts.
\end{abstract}

Keywords: Toxoplasmosis, pigs, risk factors, Northeastern Brazil.

\section{Resumo}

A toxoplasmose é uma importante zoonose para mulheres grávidas e pessoas imunossuprimidas. Os suínos também são infectados por este patógeno; e a carne crua ou malcozida é uma importante fonte de infecção para o ser humano. O objetivo do presente trabalho foi avaliar a taxa de exposição suína à T. gondii no município de Mossoró, Rio Grande do Norte e identificar associaçóes com possíveis fatores de risco. Amostras de sangue foram coletadas em tubos sem anticoagulante e o soro foi separado de 412 porcos e analisadas pelo ensaio de imunofluorescência. Dentre as 412 amostras de soro, 40,7\% foram positivas para T. gondii. Os títulos para o anticorpo IgG foram 64 (56 amostras); 128 (32); 256 (37); 512 (23); 1024 (14); 2048 (5) e 4046 (1). A soropotividade para T. gondii foi relacionada ( $p$-valor $<0,05$ ) aos seguintes fatores: gênero feminino, sistema de criação de semi-confinamento, uso de água de poço, animais vermifugados, presença de gatos, cabras, ovelhas, ratos e urubus na fazenda e carcaças deixadas à céu aberto. Em contrapartida, a soropositividade não foi relacionada $(p$-valor $<0,05)$ à idade dos suínos, tipo de instalações ou alimentação com restos de comida humana. As adoçóes de medidas preventivas são necessárias na propriedade estudada, objetivando diminuir a ingestáo de oocistos esporulados pelos animais.

Palavras-chave: Toxoplasmose, suínos, fatores de risco, Nordeste brasileiro.

\footnotetext{
*Corresponding author: Prof. Dr. Marcos Rogério André. Laboratório de Imunoparasitologia, Departamento de Patologia Veterinária, Faculdade de Ciências Agrárias e Veterinárias Júlio de Mesquita Filho - UNESP, Via de Acesso Prof. Paulo Donato Castellane, s/n, Zona Rural, CEP 14884-900, Jaboticabal, SP, Brasil. e-mail: mr.andre@unesp.br
} 


\section{Introduction}

Toxoplasma gondii is an apicomplexan protozoan that infects warm-blooded animals, including humans and cats, which play roles as intermediate and definitive hosts, respectively (TENTER et al., 2000). Toxoplasmosis is an important zoonosis for pregnant women and immunosuppressed people (SAADATNIA \& GOLKAR, 2012). The pig population also becomes infected by this pathogen, and undercooked or raw meat is an important source of infection for humans (DUBEY et al., 2002; SAADATNIA \& GOLKAR, 2012).

Previous studies in Brazil have reported serological evidence of exposure to T. gondii among pigs in the states of São Paulo (CORRÊA et al., 1978), Rondônia (CAVALCANTE et al., 2006), Paraná (MOURA et al., 2007), Paraíba (AZEVEDO et al., 2010), Bahia (BEZERRA et al., 2009), Mato Grosso (MURARO et al., 2010), Pernambuco (FERNANDES et al., 2012), Piauí (SOUSA et al., 2014) and Rio de Janeiro (LUCIANO et al., 2011). However, no studies in the state of Rio Grande do Norte have been reported.

Toxoplasmosis on pig farms leads to economic losses through abortions and birth of dead or weak offspring (ISHAKU et al., 2018). Moreover, consumption of raw and undercooked pork meat is an important form of transmission of toxoplasmosis to humans. No studies on these issues have yet been conducted in Rio Grande do Norte and this highlights the need for further investigations in this region.

Therefore, the aims of the present study were to evaluate the rate of exposure of pigs to $T$. gondii in the municipality of Mossoró, Rio Grande do Norte, and seek to identify associations with possible risk factors.

\section{Material and Methods}

\section{Ethical issues}

This study was approved by the Institutional Animal Care and Use Committee (CEUA) of the Federal University of the Semi-Arid Region (UFERSA) and was registered under the number 02/2013, with procedural number 23091.003915/2012-42 CEUA/UFERSA. It was also approved under Certificate of Presentation for Ethical Assessment (CAAE) number 13798813.7.0000.5296, with favorable final report number 290.224/2013 from the Research Ethics Committee of Potiguar University. Development of the present study complied with resolution number 466/2012 of the Ministry of Health (National Health Council). Interviewees' agreement to participate in this study was recorded on two original copies of an informed consent form that were signed by the participants after they had been given information about the study, had had an opportunity to ask questions about it and had read the statement that they would signing. One copy was given to the interviewee and the other was retained by the researcher.

\section{Sample size}

The sample size was calculated using an epidemiological formula which considered the total of 6.046 animals present in the municipality (IBGE, 2012) and assumed prevalence of 50\%, to maximize the sample size, and obtain a minimal confidence of $5 \%$ and a 5\% statistical error (THRUSFIELD, 2005). The minimum sample size was defined as 384 animals and, in the end, 412 pig blood samples were collected.

Sampling was performed at a local slaughterhouse according to convenience and the blood samples were taken according to the slaughter order, at the time of jugular bleeding, until the total of 412 serum samples was reached. These samples were collected from pigs that belonged to 20 different farms.

\section{On-site inspection of the farms}

After sampling, the farms from where the pigs belonged were visited and interviews with the farm owners were conducted using a prepared script containing open-ended and multiple-choice questions about the environment, husbandry, feeding, sanitary methods and prophylactic control methods used, along with questions seeking populational, social and economic data.

\section{Serological tests for T. gondii}

The antigen substrate of $T$. gondii consisted of purified tachyzoites from peritoneal washes of mice that had been experimentally infected with the parasite in question (RH strain) (CAMARGO, 1964). The serum samples were first diluted at 1:40 in phosphate-buffered saline solution, PBS pH $7.4(130 \mathrm{mM} \mathrm{NaCl} ; 2.7 \mathrm{mM} \mathrm{KCl}$; $5.6 \mathrm{mM} \mathrm{Na}_{2} \mathrm{HPO}_{4} ; 1.0 \mathrm{mM} \mathrm{KH} \mathrm{PO}_{4} ; 0.8 \mathrm{mM} \mathrm{NaH}_{2} \mathrm{PO}_{4}$ ). After that, $20 \mu \mathrm{L}$ of each diluted serum sample was deposited in wells of slides containing the antigen of $T$. gondii. Sera from pigs previously known to be positive and negative for the antigen of T. gondii were used as controls in each reaction. The slides were incubated at $37^{\circ} \mathrm{C}$ for 30 minutes, in a moist chamber. Afterwards, they were washed with PBS (phosphate-buffered saline solution, $\mathrm{pH}$ 7.4) three times and then dried. Each slide received $20 \mu \mathrm{L}$ conjugate (pig anti-IgG diluted at 1:32) marked by fluorescein isothiocyanate (Sigma-Aldrich', St. Louis, Missouri, United States) for test samples as well as positive and negative controls. The slides were then incubated for a further 30 minutes at $37^{\circ} \mathrm{C}$ in a moist chamber. After being washed and dried again, the slides were evaluated through ultraviolet light microscopy. The reaction was considered to be positive when $T$. gondii cells were fluorescent at 1:40 dilution, as compared to positive and negative controls serum samples.

\section{Statistical Analysis}

Associations between disease outcome and other variable categories (sex, age and others) were analyzed by means of the chi-squared test and Fisher exact test when the data was lower than 5. Associations with $p$-values less than or equal to 0.05 ( $p$-value $\leq 0.05)$ were considered statistically significant. For this purpose, the SAS software (SAS 9.1, SAS Institute, Cary, NC, USA) was used to calculate chi-squared and the R Project for Statistical Computing software (R version 3.4.4) was used for Fisher exact test. 


\section{Results}

Out of the 412 samples evaluated in the municipality of Mossoró, Rio Grande do Norte, 168 (40.7\%) were seropositive for $T$. gondii according to the immunofluorescence assay (IFA). The IgG antibody titers were 64 (56 samples), 128 (32), 256 (37), 512 (23), 1024 (14), 2048 (5) and 4046 (1) (Figure 1).
Seropositivity for $T$. gondii was found to be statistically related ( $p$-values $<0.05$ ) to the following factors: female gender, semi-confined rearing system, use of well water, dewormed animals, presence of cats, goats, sheep, mice and vultures on the farm and carcasses left on the ground. In contrast, seropositivity was not statistically related $(p$-values $<0.05)$ to the age of the pigs, type of facility or feeding with human food remains (HFR) (Table 1).

Table 1. Risk factors associated with seropositivity for T. gondii in sampled pigs from Mossoró, Rio Grande do Norte.

\begin{tabular}{|c|c|c|c|c|}
\hline & \multirow[t]{2}{*}{ Variant } & \multicolumn{2}{|c|}{$\begin{array}{c}\text { IFA } \\
\text { (Immune-Fluorescence Assay) } \\
\end{array}$} & \multirow[t]{2}{*}{$p$-values } \\
\hline & & Reagent & Not-reagent & \\
\hline \multirow[t]{3}{*}{ Gender } & Male & $67(39.88 \%)$ & $125(51.23)$ & 0.0233 \\
\hline & Female & $101(60.12 \%)$ & $119(48.77)$ & \\
\hline & Total & $168(40.78 \%)$ & $244(59.22)$ & \\
\hline \multirow[t]{3}{*}{ Age } & Young & $91(54.17 \%)$ & $135(55.33)$ & 0.8160 \\
\hline & Adult & $77(45.83 \%)$ & $109(44.67)$ & \\
\hline & Total & $168(40.78 \%)$ & $244(59.22)$ & \\
\hline \multirow[t]{4}{*}{ Production system } & Outdoor & $1(0.60)$ & $11(4.51)$ & 0.0335 \\
\hline & Semi-confinement & $108(64.29)$ & $139(56.97)$ & \\
\hline & Confinement & $59(35.12)$ & $94(38.52)$ & \\
\hline & Total & $168(40.78)$ & $244(59.22)$ & \\
\hline \multirow[t]{3}{*}{ Facilities } & Wood and dirty & $135(80.36)$ & $181(74.18)$ & 0.1450 \\
\hline & Wood, dirty and masonry & $33(19.64)$ & $63(25.82)$ & \\
\hline & Total & $168(40.78)$ & $244(59.22)$ & \\
\hline \multirow[t]{3}{*}{ Feed } & Includes HFR & $140(83.33)$ & $198(81.15)$ & 0.5700 \\
\hline & Without HFR & $28(16.67)$ & $46(18.85)$ & \\
\hline & Total & $168(40.78)$ & $244(59.22)$ & \\
\hline \multirow[t]{5}{*}{ Water source } & Well & $107(63.69)$ & $141(57.79)$ & 0.0248 \\
\hline & Rio Grande do Norte Water and Sewage Company (Caern) & $40(23.81)$ & $76(31.15)$ & \\
\hline & Pond & $17(10.12)$ & $12(4.92)$ & \\
\hline & River & $4(2.38)$ & $15(6.15)$ & \\
\hline & Total & $168(40.78)$ & $244(59.22)$ & \\
\hline \multirow[t]{3}{*}{ Presence of Birds } & Yes & $123(73.21 \%)$ & $220(90.16 \%)$ & $<0.001$ \\
\hline & No & $45(26.79 \%)$ & $24(9.84 \%)$ & \\
\hline & Total & $168(40.78 \%)$ & $244(59.22 \%)$ & \\
\hline \multirow[t]{3}{*}{ Presence of Goats and Sheep } & Yes & $98(58.33 \%)$ & $101(41.39 \%)$ & 0.0007 \\
\hline & No & $70(41.67 \%)$ & $143(58.61 \%)$ & \\
\hline & Total & $168(40.78 \%)$ & $244(59.22 \%)$ & \\
\hline \multirow[t]{3}{*}{ Presence of Cats } & Yes & $37(22.02 \%)$ & $81(33.20 \%)$ & 0.0137 \\
\hline & No & $131(77.98 \%)$ & $163(66.80 \%)$ & \\
\hline & Total & $168(40.78 \%)$ & $244(59.22 \%)$ & \\
\hline \multirow[t]{3}{*}{ Presence of Vultures } & Yes & $43(25.60 \%)$ & $39(15.98 \%)$ & 0.0163 \\
\hline & No & $125(74.40 \%)$ & $295(84.02 \%)$ & \\
\hline & Total & $168(40.78 \%)$ & $244(59.22 \%)$ & \\
\hline \multirow[t]{3}{*}{ Presence of Mice } & Yes & $135(80.36 \%)$ & $146(59.84 \%)$ & $<0.001$ \\
\hline & No & $33(19.64 \%)$ & $98(40.16 \%$ & \\
\hline & Total & $168(40.78 \%)$ & $244(59.22 \%)$ & \\
\hline \multirow[t]{4}{*}{ Carcass disposal } & Natural disposal (ground) & $76(45.24 \%)$ & $169(61.07 \%)$ & 0.0042 \\
\hline & Burial & $44(26.19 \%)$ & $39(15.98 \%)$ & \\
\hline & Burning & $48(28.57 \%)$ & $56(22.95 \%)$ & \\
\hline & Total & $168(40.78 \%)$ & $244(59.22 \%)$ & \\
\hline \multirow[t]{3}{*}{ Zoonosis definition } & Yes & $35(20.83 \%)$ & $20(8.20 \%)$ & 0.0002 \\
\hline & No & $133(79.17 \%)$ & $224(91.80 \%)$ & \\
\hline & Total & $168(40.78 \%)$ & $244(59.22 \%)$ & \\
\hline
\end{tabular}




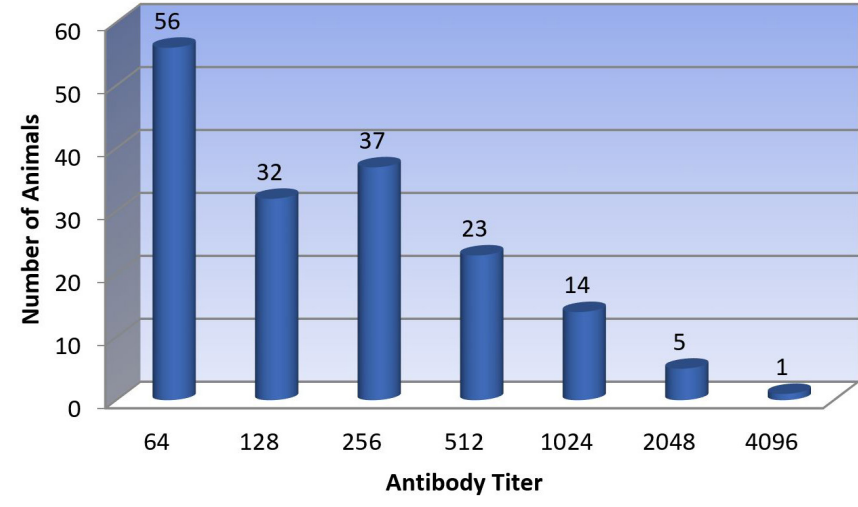

Figure 1. Distribution of animals that tested seropositive for T. gondii antigen, according to their antibody titers.

\section{Discussion}

Studies on frequency of antibodies for T. gondii among pigs in Brazil have indicated that the seropositivity rates are between $7.64 \%$ and $43.1 \%$ in farms with different production systems (MOURA et al., 2007; MILLAR, et al., 2008; MURARO et al., 2010; LUCIANO et al., 2011; CORRÊA et al., 1978; CAVALCANTE et al., 2006; SAMICO FERNANDES et al., 2012; SOUSA et al., 2014; AZEVEDO et al., 2010). Accordingly, IFA was the serological technique used in the aforementioned studies. Furthermore, this test shows sensitivity of $80.4-100 \%$ and specificity of $91.4-95.8 \%$ (LIU et al., 2015). In the present study, the seropositivity for $T$. gondii among pigs in the municipality of Mossoró, state of Rio Grande do Norte, was $40.7 \%$, i.e. similar to the highest seropositivity rate previously reported in any serological studies in Brazil.

Analysis on the risk factors associated with T. gondii infection is important when the main purpose is to adopt control measures and prophylaxis against swine toxoplasmosis. In the present study, there was a significant difference between the genders regarding seropositivity, since the female sex was $39.88 \%$ for male and $60.12 \%$ for female) associated with higher seroreactivity for T. gondii, corroborating previous studies (BONNA et al., 2006; MILLAR et al., 2008; BEZERRA et al., 2009; SOUSA et al., 2014) However, this association may probably occur due to a sample bias instead of a sex related susceptibility (SILVA et al., 2010).

It is known that age is an important risk factor, since T. gondii seroprevalence increases along with the animal's age due to a longer exposure to a contaminated environment (SOUSA et al., 2014; ISHAKU et al., 2018). However, in this study, age was not shown to be a risk factor associated with the presence of anti-T. gondii antibodies, thus corroborating some previous studies (LUCIANO et al., 2011; MILLAR et al. 2008).

Variations in the production systems and geographical/regional differences are elements that reportedly influence the seroprevalence in several regions (ISHAKU et al., 2018). The production system associated with highest seropositivity for T. gondii was semi-confinement, compared with total confinement and outdoor systems. Although extensive and semi-extensive systems favor greater contact with sporulated oocysts in the environment (MARANA et al., 1994), this association was not observed in previous studies on cattle (FAJARDO et al., 2013). Moreover, in another study, hardy extensive pig breeding systems were considered to be a risk factor, compared with intensive commercial breeding systems, possibly due to the greater exposure of the animals in the extensive system to sporulated oocysts that were present in the soil and water of the region studied (BEZERRA et al., 2009).

The feeding variable, which evaluated whether human food remains (HFR) were included in the food offered to the animals, was not a significant risk factor in the present study. However, a study conducted by Sousa et al. (2014) in the state of Piauí showed that pigs fed with human food remains showed higher seropositivity for $T$. gondii than did those that were fed with commercial animal feed or a combination of these two diets. Although the main risk factor is the food source, which would make HFR more susceptible to contamination by oocysts, such contamination does not necessarily occur, as suggested from the data analysis of the present study.

The facility type (combinations of wood and daub versus wood and masonry) showed no association with seropositivity for T. gondii. The resistance of sporulated oocysts in environments with daub is probably higher than that seen in masonry facilities, in which cleaning and hygiene processes are conducted frequently. However, it is worth noting that without presence of the definitive hosts in the facility, environmental contamination is unlikely. Furthermore, presence of the definitive hosts is crucial for enabling contamination, regardless of the installation type.

Regarding the water source, animals on farms on which the water came from wells showed higher seropositivity for T. gondii than did those that ingested water from ponds or rivers. It is possible that such water source had higher contamination with sporulated oocysts than did water from ponds and rivers. This would indicate the presence of cats wandering around the water collection points and thus shedding non-sporulated oocysts. However, if the water collection points are properly isolated, the risk tends to be lower, since isolation prevents environmental contamination by sporulated oocysts (PIASSA et al., 2010).

Another risk factor associated with seropositivity for T. gondii among the pigs in the present study was the presence of birds on the farms that were sampled, especially vultures. The infection rate among birds in certain areas is decisive for the T. gondii infection rate among cats (LINDSAY \& DUBEY, 2014). Birds play a role as intermediate hosts in this parasite's epidemiological cycle and can also mechanically transport sporulated oocysts on their legs and feet, as also envisaged in relation to other animal species (LINDSAY et al., 1997).

The presence of rodents on the farm, which also act as intermediate hosts for $T$. gondii, was identified as a significant risk factor. The rodent infection rate in certain areas is also decisive in relation to the feline infection rate (LINDSAY \& DUBEY, 2014). This animal group, just like birds, plays a role in the parasite's epidemiological cycle, through harboring cysts in the musculature and nervous system and acting as a source of infection for cats. In addition, rodents may also mechanically transport sporulated oocysts. 
Another risk factor associated with $T$. gondii infection in the present study was the presence of goats and sheep on the farms. Small ruminants are particularly sensitive to $T$. gondii infection, and the main clinical manifestation in these animals is abortion. Fetal death, neonatal death and mummification generate important economic losses (ASGARI et al., 2011; DUBEY, 2009). An aborted fetus harboring the parasite in its tissue acts as a source of infection for young and non-immune cats, which then shed non-sporulated oocysts in their feces around the farm after the entero-epithelial cycle has been completed. A previous study showed that there was an association between higher numbers of different animal species on the farms from which samples were obtained and higher occurrence of seropositive samples (FAJARDO et al., 2013).

The presence of cats is pointed as a risk factor by several studies (SOUSA et al., 2014; GUO et al., 2015). However, the onsite inspection and the questionnaire revealed that few of the studied farms owned cats and the ones that lacked cats, were also positive against $T$. gondii. Even though some farms did not own these animals, stray cats can still be present at the perimeters and since they have nocturnal habits, they are able to hide in the environs of the studied farms and wander around at night.

Regarding the disposal of carcasses from slaughtered or deceased pigs, the farms that practiced natural disposal (i.e. carcasses left to rot on the ground) presented a higher seropositivity rate than did those on which the carcasses were buried or burned. A previous study showed that pig carcasses might act as a source of T. gondii infection (MILLAR et al., 2008). Inadequate disposal of carcasses is a known risk factor for T. gondii infection (GUO et al., 2015). Thus, cats and especially young and non-immune cats that ingested pig carcasses can shed oocysts in their feces, which contributes towards future infection of naïve animals.

Lack of knowledge of zoonosis definitions among pig farm workers also showed a significant association with pig seropositivity for T. gondii. Since pig farm workers do not know about the disease and its transmission routes, measures that would prevent or control occurrences of this parasite within a given farm are not taken. At slaughterhouses, pig carcasses may act as a source of T. gondii infection for butchers and other workers (MILLAR et al., 2008). For instance, Millar et al. (2008) found seropositivity of $58.6 \%$ among 156 slaughterhouse workers in the southwestern region of the state of Paraná state. This demonstrates that there is a need for proper sanitary education among pig farm and slaughterhouse workers, to reduce pathogen transmission to these employees.

Considering the economic losses and the importance of toxoplasmosis in Public Health, associated with the high serological evidence of exposure to T. gondii in backyard pig production in the city of Mossoró (40,7\%), preventive measures need to be adopted on the studied farms in the light of the risk factors raised in the present study.

\section{Acknowledgements}

MRA is a fellowship researcher of "Conselho Nacional de Desenvolvimento Científico e Tecnológico” (CNPq Process number \# 302420/2017-7).

\section{References}

Asgari Q, Sarnevesht J, Kalantari M, Sadat SJA, Motazedian MH, Sarkari B. Molecular survey of Toxoplasma infection in sheep and goat from Fars province, Southern Iran. Trop Anim Health Prod 2011; 43(2): 389-392. http://dx.doi.org/10.1007/s11250-010-9704-1. PMid:20936348.

Azevedo SS, Pena HFJ, Alves CJ, Guimarães Filho AAM, Oliveira RM, Maksimov P, et al. Prevalence of anti-Toxoplasma gondii and anti-Neospora caninum antibodies in swine from Northeastern Brazil. Rev Bras Parasitol Vet 2010; 19(2): 80-84. http://dx.doi.org/10.1590/ S1984-29612010000200002. PMid:20624342.

Bezerra RA, Paranhos EB, Del'Arco AE, Albuquerque GR. Detection anti-Toxoplasma gondii antibodies in swines bred and abated in the Bahia State, Brazil. Rev Bras Parasitol Vet 2009; 18(3): 78-80. http://dx.doi. org/10.4322/rbpv.01803015. PMid:19772782.

Bonna ICF, Figueiredo FB, Costa T, Vicente RT, Santiago CAD, Nicolau JL, et al. Estudo soroepidemiológico da infecção por Toxoplasma gondii em suínos e frangos, para abate, em região rural do Rio de Janeiro. $R$ Bras Ci Vet 2006; 13(3): 186-189.

Camargo ME. Improved technique of indirect immunofluorescence for serological diagnosis of toxoplasmosis. Rev Inst Med Trop São Paulo 1964; 6: 117-118. PMid:14177810.

Cavalcante GT, Aguiar DM, Chiebao D, Dubey JP, Ruiz VLA, Dias RA, et al. Seroprevalence of Toxoplasma gondii antibodies in cats and pigs from rural Western Amazon, Brazil. J Parasitol 2006; 92(4): 863-864. http://dx.doi.org/10.1645/GE-830R.1. PMid:16995406.

Corrêa FM, Salata E, Oliveira MR. Toxoplasma gondii: indirect immunofluorescence diagnosis in swine in the State of São Paulo, Brazil. Arq Inst Biol (Sao Paulo) 1978; 45(4): 209-212. PMid:383046.

Dubey JP. Toxoplasmosis in pigs - The last 20 years. Vet Parasitol 2009; 164(2-4): 89-103. http://dx.doi.org/10.1016/j.vetpar.2009.05.018. PMid:19559531.

Dubey JP, Gamble HR, Hill D, Sreekumar C, Romand S, Thuilliez P. High prevalence of viable Toxoplasma gondii infection in market weight pigs from a farm in Massachusetts. J Parasitol 2002; 88(6): 1234-1238. http://dx.doi.org/10.1645/0022-3395(2002)088[1234:HPOVTG]2.0 .CO;2. PMid:12539744.

Fajardo HV, D'ávila S, Bastos RR, Cyrino CD, Detoni ML, Garcia $\mathrm{JL}$, et al. Seroprevalence and risk factors of toxoplasmosis in cattle from extensive and semi-intensive rearing systems at Zona da Mata, Minas Gerais state, Southern Brazil. Parasit Vectors 2013; 6(1): 191. http:// dx.doi.org/10.1186/1756-3305-6-191. PMid:23800302.

Fernandes EFTS, Fernandes MFTS, Kim PCP, Albuquerque PPF, Souza OL No, Santos AS, et al. Prevalence of Toxoplasma gondii in Slaughtered Pigs in the State of Pernambuco, Brazil. J Parasitol 2012; 98(3): 690-691. http://dx.doi.org/10.1645/GE-3032.1. PMid:22263703.

Guo M, Dubey JP, Hill D, Buchanan RL, Gamble HR, Jones JL, et al. Prevalence and risk factors for Toxoplasma gondii infection in meat animals and meat products destined for human consumption. J Food Prot 2015; 78(2): 457-476. http://dx.doi.org/10.4315/0362-028X.JFP-14-328. PMid:25710166.

Instituto Brasileiro de Geografia e Estatística - IBGE [online]. Rio de Janeiro: IBGE; 2012 [cited 2012 May 5]. Available from: https://www. ibge.gov.br 
Ishaku BS, Abdullahi M, Nalong D, Jonah R, Mayowa O. Seroprevalence and risk factors for Toxoplasma gondii in pigs, sheep and goats at slaughter in Jos Municipal Abbatoir, Nigeria. Vet Sci Res Rev 2018; 4(2): 55-61.

Lindsay DS, Dubey JP, Butler JM, Blagburn BL. Mechanical transmission of Toxoplasma gondii oocysts by dogs. Vet Parasitol 1997; 73(1-2): 27-33. http://dx.doi.org/10.1016/S0304-4017(97)00048-4. PMid:9477489.

Lindsay DS, Dubey JP. Toxoplasmosis in wild and domestic animals. In: Weiss LM, Kim K, editors. Toxoplasma gondii - the model apicomplexanperspectives and methods. 2nd ed. Massachussets: Academic Press Books; 2014. p. 193-215. http://dx.doi.org/10.1016/B978-0-12-396481-6.00006-4.

Liu Q, Wang ZD, Huang SY, Zhu XQ. Diagnosis of toxoplasmosis and typing of Toxoplasma gondii. Parasit Vectors 2015; 8(1): 292. http://dx.doi. org/10.1186/s13071-015-0902-6. PMid:26017718.

Luciano DM, Menezes RC, Ferreira LC, Nicolau JL, Neves LB, Luciano RM, et al. Occurence of anti-Toxoplasma gondii antibodies in cattle and pigs slaughtered, State of Rio de Janeiro. Rev Bras Parasitol Vet 2011; 20(4):351-353. http://dx.doi.org/10.1590/S1984-29612011000400018. PMid:22166394.

Marana ERM, Navarro IT, Vidotto O, Freire RL, Lott R. Ocorrência de anticorpos anti-Toxoplasma gondii em bovinos de corte, abatidos em matadouros do norte do Paraná - Brasil. Semina: Ciênc Agrár 1994; 15(1): 38-40.

Millar PR, Daguer H, Vicente RT, Costa T, Sobreiro LG, Amendoeira MRR. Toxoplasma gondii: estudo soro-epidemiológico de suínos da região Sudoeste do Estado do Paraná. Pesq Vet Bras 2008; 28(1): 15-18. http:// dx.doi.org/10.1590/S0100-736X2008000100002.

Moura AB, Osaki SC, Zulpo DL, Marana ER. Occurrence of antiToxoplasma gondii antibodies in swine and ovine slaughtered at municipality of Guarapuava in the State of Paraná, Brazil. Rev Bras Parasitol Vet 2007; 16(1): 54-56. PMid:17588324.

Muraro LS, Caramori JG Jr, Amendoeira MRR, Pereira JA, Oliveira JX Fo, Vicente RT, et al. Seroprevalence of Toxoplasma gondii infection in swine matrices in Nova Mutum and Diamantino, Mato Grosso, Brazil. Rev Bras Parasitol Vet 2010; 19(4): 254-255. http://dx.doi.org/10.1590/ S1984-29612010000400012. PMid:21184704.

Piassa FR, Araújo JB, Rosa RC, Mattei RJ, Silva RC, Langoni H, et al. Prevalence and risk factors for Toxoplasma gondii infection in certified and non-certified pig breeding farms in the Toledo microregion, PR, Brazil. Rev Bras Parasitol Vet 2010; 19(3): 152-156. http://dx.doi.org/10.1590/ S1984-29612010000300005. PMid:20943018.

Saadatnia G, Golkar M. A review on human toxoplasmosis. Scand J Infect Dis 2012; 44(11): 805-814. http://dx.doi.org/10.3109/00365548.2012 .693197. PMid:22831461.

Silva AV, Silva RC, Zamprogna TO, Lucas TM. Toxoplasma gondii em suínos com ênfase na contribuição brasileira. Scie Med 2010; 20(1): 120-130.

Sousa RA, Lemos JF, Farias LA, Lopes CD, Santos KR. Seroprevalence and risk factors for Toxoplasma gondii infection in pigs in southern Piauí. Rev Bras Parasitol Vet 2014; 23(1): 98-100. http://dx.doi.org/10.1590/ S1984-29612014015. PMid:24728369.

Tenter AM, Heckeroth AR, Weiss LM. Toxoplasma gondii: from animals to humans. Int J Parasitol 2000; 30(12-13): 1217-1258. http://dx.doi. org/10.1016/S0020-7519(00)00124-7. PMid:11113252.

Thrusfield M. Veterinary epidemiology. 3th ed. Oxford: Balckwell Science; 2005. 610 p. 